\title{
Improvement in the efficiency of hydrolysis of anaerobic digestion in sewage sludge by the use of enzymes
}

\author{
Ibrahim Gar Al-Alm Rashed a, Joseph Akunnab , Mohamed Mohamed El-Halwany ${ }^{a *}$ \\ Ahmed Farag Fadil Abou Atiaa ${ }^{c}$ \\ ${ }^{a}$ Engineering, Mathematics and Physics Department, Faculty of Engineering, Mansoura University, Egypt \\ Tel.+20 123455789; Mobile+20 125945904; email: halwany22@yahoo.com; halwany22@hotmail.com \\ ${ }^{b}$ Environment Education, University of Abertay Dundee \\ ${ }^{\circ} \mathrm{KAHA}$ CO for Chemical Industries, Egypt
}

Received 13 October 2009; accepted 18 February 2010

\section{A B S T R A C T}

The effects of enzymatic pre-treatment on a mixture of sludge (primary, secondary, digested) collected from different municipal wastewater-treatment plants was investigated by Batch experiments in the laboratory to enhance the hydrolysis of sludge. The experiments were carried out at mesophilic $\left(37^{\circ} \mathrm{C}\right)$ temperature. Six commercially available enzymes, supplied by Novo Industries, were used which ware Alcalase, Caresyme, Celluclast, Lipolase, Termamyl and Viscosyme. The experiment showed that with $50 \%$ digested sludge and $0.1 \%$ enzyme dosage of Carezyme and the mixed enzymes there was $11.5 \%$ and $10.6 \%$ decrease in volatile solids (VS), whereas with $25 \%$ digested sludge and $0.1 \%$ Viscosyme enzyme was very much effective for VS reduction compared with the blank (it shows $16.3 \%$ higher than blank). In another set of experiments, which differed in sludge characteristics with $25 \%$ digested sludge and $0.5 \%$ enzyme dosage the culture containing the mixed enzymes presents the highest percentage of VS reduction among all the samples (13.6\% higher than blank), where with $25 \%$ digested sludge and $0.5 \%$ enzyme dosage of Termamyl and mixed enzymes show $13.5 \%$ and $12.8 \%$ greater VS reduction respectively compared with the blank. The experimental work showed that enzymatic pre-treatment can be successfully used as a pre-treatment step for treating sludge mixture produced from municipal wastewater treatment plant and the performance of individual enzymes largely depends on the characteristics of sludge.

Keywords: Sewage Sludge; Enzymes; Hydrolysis; Anaerobic digestion

\section{Introduction}

Sludge produced from wastewater treatment plants is globally one of the major sources of pollution. The cost of sludge management include processing, transporting and disposal may be reach up to $65 \%$ of the total cost of operating a wastewater treatment works (WWTW) [1]. The cost of sludge disposal is usually

${ }^{*}$ Corresponding author calculated per unit volume, hence a decrease in the volume that must be disposed of can represent a significant cost saving.

Moreover, with increase in legislation with respect to produced cleaner WWTW effluents, more volumes of sludge are being generated. For example, sludge production in the European Union (EU) had risen to more than 10 million tonnes per annum by the end of 2005 [2]. In the United States alone the production of Municipal Solid Waste (MSW) is projected to 
increase to about 262 million tons in the year 2010 from 209 million tons in 1994 [3]. Researchers agree that there are three main way for final disposal of sludge and sludge components as follow:

1. Deposited in land (in landfills or special sludge deposits), in the sea (ocean disposal) or in the air (mainly as a consequence of incineration),

2. Used of treated sludge as fertilizer or as one of the intergradient in constructed "bio-soils" or

3. Sludge and sludge components may by recycled as useful products such as "bio-soils" (mixture of sludge with other materials), energy (biogas, electricity, oil, heat, etc.), nutrients (phosphate, nitrogen), and metals (coagulants).

During digestion anaerobic bacteria convert high and complex organic compound molecules through a complex set of processing to methane and carbon dioxide. This means reduction in the volume of the sludge which became more stable. The final digested sludge can be used in agriculture, land reclamation and forestry, recycling through composting and minor uses such as building materials, fuels, incineration and disposal to landfill [2].

Technologies have been developed to further the cause of biological treatment by aiding in cell lysis. This led to the development of pre-treatment processes. These techniques will improve sludge handling and disposal [4].

The anaerobic digestion process can be either carried out at mesophilic or thermophilic temperature. Mesophilic anaerobic digestion of sewage sludge is more widely used, mainly because of the lower energy requirements and higher stability of the process [5].

The factors that affect on the performance of anaerobic digestion process are: temperature, $\mathrm{pH}$, alkalinity, nutrient requirements, presence of toxic compounds, loading, hydraulic retention time (HRT) and mixing.

Steady temperature at either mesophilic $\left(25-40^{\circ} \mathrm{C}\right)$ or thermophilic $\left(50-65^{\circ} \mathrm{C}\right)$ is an important conditions in the performance of anaerobic digestion process. Generally, the rate of methane production increases as the temperature increases [6].

The operational range of $\mathrm{pH}$ should be between 6.6 and 7.6, with the optimum range being 7.0-7.2 [7]. The $\mathrm{pH}$ of a digester may drop to below 6.6 if there is an excessive accumulation of volatile fatty acids, due to excessively high organic loading and/or the presence of toxic materials in the digester. Low $\mathrm{pH}$ produces inhibitory effects to the methanogen. The acidforming bacteria can tolerate a $\mathrm{pH}$ as low as 5.5 [8].

Micro-organisms require sufficient quantities of macro-nutrients and micro-nutrients for growth. The carbon, nitrogen and phosphorus ratio $(\mathrm{C}: \mathrm{N}: \mathrm{P})$ suitable for anaerobic digestion is about 100:2.5:0.5 [9].

For the digestion of organic wastes such as human excreta, animal manure, and other agricultural residues, accumulation of volatile fatty acids, $\mathrm{H}_{2}$ and undissociated ammonia $\left(\mathrm{NH}_{3}\right)$ is commonly associated with digester failure. The presence of molecular oxygen $\left(\mathrm{O}_{2}\right)$ is also inhibitory to the methanogen. Organic wastes containing inhibitors should be pre-treated or diluted to reduce the inhibitory compounds to low tolerant levels [10].

A high organic loading will normally result in excessive volatile fatty acid production in the digester with a consequent decrease in $\mathrm{pH}$, and will adversely affect the methanogenic bacteria. A low organic loading will not provide a sufficient quantity of biogas for other uses, but will make the digester unnecessarily large. Optimum organic loading to suspended growth digesters have been reported to be $1-4 \mathrm{~kg} \mathrm{VS} / \mathrm{m}^{3} \mathrm{~d}$ and 1-6 kg COD $/ \mathrm{m}^{3}$ day [11].

Hydraulic retention time has an significant effect on digester performance. Too short an HRT will not allow sufficient time for anaerobic bacteria, especially the methane-forming bacteria, to metabolise the wastes. Too long an HRT could result in an excessive accumulation of digested materials in the digester, and construction of a digester which is too large [12]. An optimum range of HRT for suspended growth digesters falls within the range 10-60 days; while attached growth and high rate digesters can be operated at a much shorter HRT [13]. Shorter HRT can also be applied for higher digester temperatures.

Anaerobic digestion can be improved by breakdown of large, organic particulate matter into smaller one to increase the surface area available for contact with bacteria responsible for degradation in order to improve the efficiency of digested process [14].

This study provides an overview on pre-treatment processes of the sludge in general and focuses on microbial-enzyme pre-treatment which have advantage in behavior and lower cost comparing with other pre-treatment methods.

\section{Materials and methods}

\subsection{Sludge collection}

The sludge samples were collected from different wastewater treatment plants treating domestic wastewater around Dundee - Scotland. These plants are operated and maintained by the Scottish Water. The primary sludge was collected from primary settling tank from a plant that uses trickling filter process and the secondary sludge was collected from aeration tank from a plant using conventional activated sludge 
Table 1

Average total solid in raw sludge

\begin{tabular}{lll}
\hline Type of sludge & $\begin{array}{l}\text { First experiment } \\
\text { total solid } \\
\text { (TS) } \mathrm{mg} / \mathrm{l}\end{array}$ & $\begin{array}{l}\text { Second experiment } \\
\text { total solid } \\
\text { (TS) } \mathrm{mg} / \mathrm{l}\end{array}$ \\
\hline Primary & 28 & 26.7 \\
Secondary & 5.6 & 11.7 \\
Digested & 29 & 25.7 \\
\hline
\end{tabular}

process. The digested sludge was collected from anaerobic sludge digester near Dundee (Table 1).

\subsection{Sample preparation}

Two sludge mixtures were prepared from the three types sludge. First mixtures contained $50 \%$ of solid content from the digested sludge and the rest of the $50 \%$ of the solid content was from the primary and secondary sludge in equal proportion. The other mixture contains 25\% solid weight from digested sludge and the rest of the solid content was from the primary and secondary sludge in equal proportion. The $\mathrm{pH}$ of two mixtures was adjusted to (7.5).

Batch experiments were carried out using synthetic wastewater based on a sludge solution in which the carbon content of this feed was contributed by sludge and other macro and micronutrients were present to balance the solution. The $\mathrm{pH}$ of the solution was increased by the addition of sodium hydrogen carbonate solution. The composition of the chemical solution is given in Table 2 .

\subsection{Types of enzymes}

Six commercially available enzymes supplied by Novo Industries, Bagsvaerd, Denmark were used to

Table 2

Chemical composition of stock solution

\begin{tabular}{ll}
\hline Material & $\begin{array}{l}\text { Concentration } \\
(\mathrm{mg} / \mathrm{l})\end{array}$ \\
\hline $\begin{array}{l}\text { Sodium hydrogen carbonate }\left(\mathrm{NaHCO}_{3}\right) \\
\text { Ammonium Chloride }\left(\mathrm{NH}_{4} \mathrm{Cl}\right)\end{array}$ & 500 \\
Potassium di-hydrogen $\mathrm{Phosphate}$ & 530 \\
$\quad\left(\mathrm{KH}_{2} \mathrm{PO}_{4}\right)$ & 2,700 \\
Potassium hydrogen phosphate & 3,500 \\
$\quad\left(\mathrm{~K}_{2} \mathrm{HPO}_{4}\right)$ & \\
Calcium chloride $\left(\mathrm{CaCl}_{2}\right)$ & 5 \\
Magnesium sulphate $\left(\mathrm{MgSO}_{4}\right)$ & 5 \\
Ferric chloride $(\mathrm{FeCl})_{3}$ & 5 \\
Potassium chloride $(\mathrm{KCl})$ & 5 \\
Cobalt chloride $\left(\mathrm{CoCl}_{2}\right)$ & 1 \\
Nickel chloride $\left(\mathrm{NiCl}_{2}\right)$ & 1 \\
\hline
\end{tabular}

observe the performance of adding enzyme for sludge pre-treatment. Types of enzymes used are:

- Alcalase (proteases)

- Carezyme (cellulases)

- Cellclast

- Lipolase (lipases)

- Termamyl

- Viscosyme

\subsection{Methods}

Batch reactors experiments in $8 \times 500 \mathrm{ml}$ conical flasks were conducted at a temperature of $37^{\circ} \mathrm{C}$ temperature. Six flasks were used for six different types of enzymes each at the same concentration. One flask was used for the mixture of enzymes and one flask was used as blank (without any enzyme).

\subsubsection{Substrate}

For the first experiment, the first mixture of $50 \%$ solid content from digested sludge, the substrate was prepared by taking $50 \mathrm{ml}$ of primary sludge, $250 \mathrm{ml}$ of secondary sludge, $100 \mathrm{ml}$ of digested sludge and $100 \mathrm{ml}$ of chemical solution to add up to $500 \mathrm{ml}$ for each of the $1,000 \mathrm{ml}$ size conical flask.

For the second mixture of $25 \%$ solid content from digested sludge, the substrate was prepared by taking $50 \mathrm{ml}$ of primary sludge, $250 \mathrm{ml}$ of secondary sludge, $50 \mathrm{ml}$ of digested sludge and $150 \mathrm{ml}$ of chemical solution to add up to $500 \mathrm{ml}$ for each of the 1,000 ml size conical flask.

\subsubsection{Enzyme dosage}

Enzyme dosage rate was calculated based on the concentration of total solids (TS) that was found in the mixed sludge. For the first set of experiments $0.1 \%$ of the enzyme were used for the two mixtures. For the second set of experiments $0.1 \%$ and $0.5 \%$ of the enzyme were used respectively for the same mixture.

\subsubsection{Experimental conditions}

The $\mathrm{pH}$ was measured using 240 Corning $\mathrm{pH}$ meter (Orion model 420A with auto temperature compensation probe). The $\mathrm{pH}$ meter was calibrated regularly by a pH 7.00 and 4.00 buffer. Temperature of the flasks containing the mixture was kept in one autoclave which was set at $37^{\circ} \mathrm{C}$. Shakers of the autoclaves were set at $60 \mathrm{rpm}$ to ensure uniform mixing.

$\mathrm{pH}$ was adjusted for 11 days for the samples of sludge and $10 \mathrm{ml}$ was collected from each flask to measure the total solid (TS) and volatile solid (VS) every 


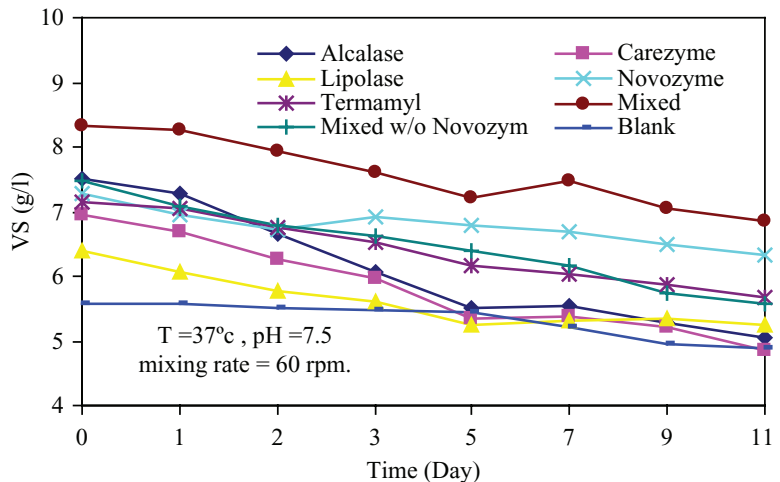

Fig. 1. Volatile Solids (VS) concentrations with change of time (50\% digested sludge and $0.1 \%$ enzyme).

day. (TS) and (VS) was measured according to methods for the examination of waters and associated materials by Standing Committee of Analysts.

After the first set of experiments ware finished, the experimental set was repeated again by using new sludge mixture and different enzyme dosage with $0.1 \%$ and $0.5 \%$.

\section{Results and discussion}

\subsection{First experiment}

3.1.1. Enzymatic hydrolysis of mixed sludge contains $50 \%$ of solid content from digested sludge and use $0.1 \%$ enzyme dosage

Fig. 1 shows the corresponding volatile solids (VS) reduction for the eight samples with respect to time for 11 consecutive days at a temperature of $37^{\circ} \mathrm{C}$. The graph shows that there is a clear advantage of enzyme addition compared with blank in terms of VS reduction. The trend of VS reduction with time is different for each type of enzyme. The mixed enzymes shows significant VS reduction during the first five days of the experiments and uniform VS reduction rate during the rest of the experimentation period. During the first five days of the experiments the trend of VS reduction is almost similar for the other type of enzymes. The termamyl and lipolase enzyme showed almost uniform VS reduction rate during the whole period of experimentation. Caresyme shows significant VS reduction during the first three days then the reduction rate was nearly constant from 3rd day to 6th day and then a sudden drop during the last days of the experiments.

3.1.2. Enzymatic hydrolysis of mixed sludge contain $25 \%$ digested sludge, $0.1 \%$ enzyme dosage

Fig. 2 shows the corresponding volatile solids (VS) reduction for the eight samples with respect to time, for

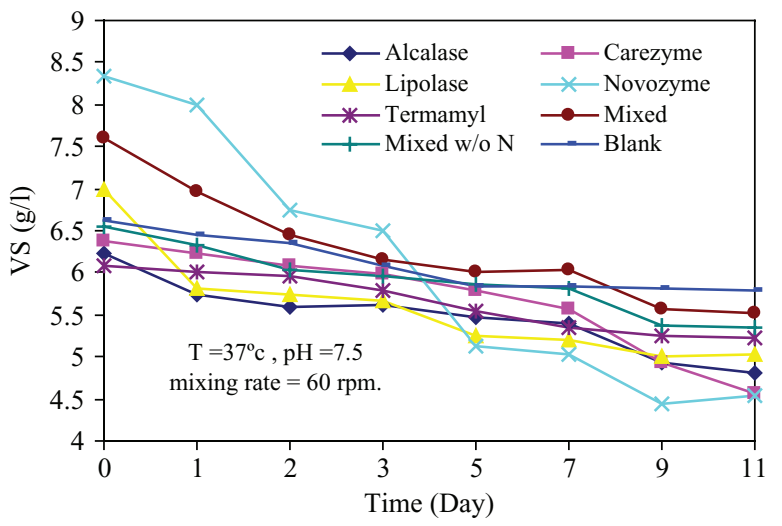

Fig. 2. Volatile Solids (VS) concentrations with change of time ( $25 \%$ digested sludge, $0.1 \%$ enzyme).

12 consequent days at a temperature of $37^{\circ} \mathrm{C}$. The figure indicates that Viscosyme shows fast and significant reduction in VS during the first three days and uniform VS reduction rate during the rest of the experimentation period, $16.28 \%$ higher than blank one. Lipolase, Termamyl and Mixed enzymes shows significant VS reduction during the first five days of the experiments and uniform VS reduction rate during the rest of the experimentation period. Alcalase, Caresyme, shows a little effect during the first five days of the experiments and then significant VS reduction rate during the rest of the experimentation period. Celluclast shows a little effect during the whole period of the experiments.

However, during the first five days of the experiments the major amount of VS reduction is observed compared with the following days. This result shows similarity with the previous results where the major portion of the VS concentration was reduced during the first three days. The retention time for the hydrolysis process is dependant on the characteristics of the sludge. However, both sets of experiments reveal that the VS reduction is high during the initial days of the experiments.

\subsection{Second experiment}

3.2.1. Enzymatic hydrolysis of mixed sludge contain $50 \%$ of solid content from digested sludge and use 0.5\% enzyme dosage

Fig. 3 shows the corresponding volatile solids (VS) reduction for the eight samples with respect to time, for 10 consecutive days at a temperature of $37^{\circ} \mathrm{C}$. The graph shows that mixed enzymes and Caresyme shows fast VS reduction during the first three days then constant reduction rate until 5th day while it was uniformly during the rest period of experimentation. 


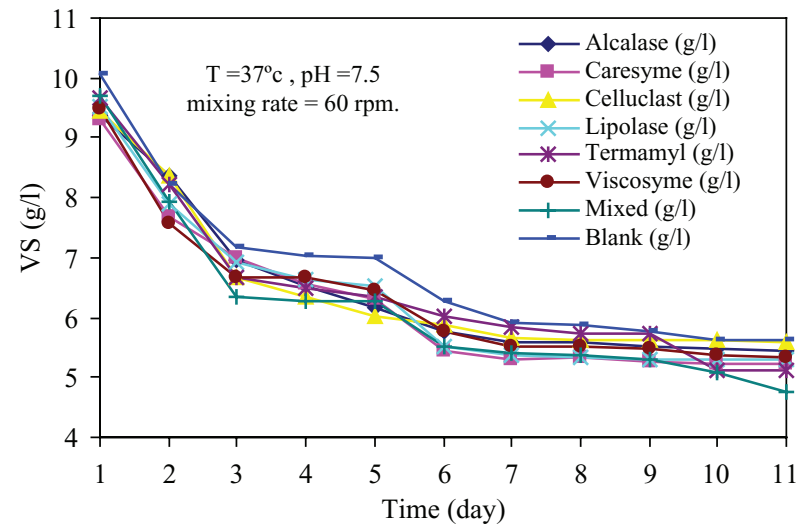

Fig. 3. Volatile Solids (VS) concentrations with change of time ( $50 \%$ digested sludge, $0.5 \%$ enzyme).

Celluclast shows large VS reduction at the 5th day than other types of enzymes while the reduction rate was nearly constant during the last days of the experiments. Termamyl shows a good effect during the first 5 days and little effect from 5th day to 8 th day while suddenly drop during last two days of experiment. Other types of enzymes showed almost uniform VS reduction rate during the whole period of experimentation.

The figure shows that the culture containing mixed enzymes presents highest percentage of VS reduction among all the samples (13.56\% higher than blank). However, Viscozyme, Lipolase and caresyme enzyme also showed significant VS reduction compared to blank $(7.98 \%, 9.6 \%$ and $8.2 \%$, respectively).

\subsubsection{Enzymatic hydrolysis of mixed sludge contain} $25 \%$ digested sludge, $0.5 \%$ enzyme dosage

Fig. 4 shows the corresponding volatile solids (VS) reduction for the eight samples with respect to time, for 10 consequent days at a temperature of $37^{\circ} \mathrm{C}$.

The graph shows that mixed enzymes shows significant VS reduction during the first five days of the experiments and uniform VS reduction rate during the rest period of experimentation. During the first five days of the experiments the trend of VS reduction is almost similar for all type of enzymes. The Alcalase showed the highest VS reduction during the first three days. Caresyme shows significant VS reduction during the first three days then the reduction rate was nearly constant after five days.

The termamyl and the mixed enzymes show $13.5 \%$ and $12.8 \%$ higher VS reduction respectively compared with the blank. Alcalase, Viscosyme and Caresyme show $11.7 \%, 11.9 \%$ and $11.1 \%$ higher VS reduction respectively compared with the blank. Lipolase and Celluclast show the least $10.2 \%$ and $9.9 \%$, respectively.

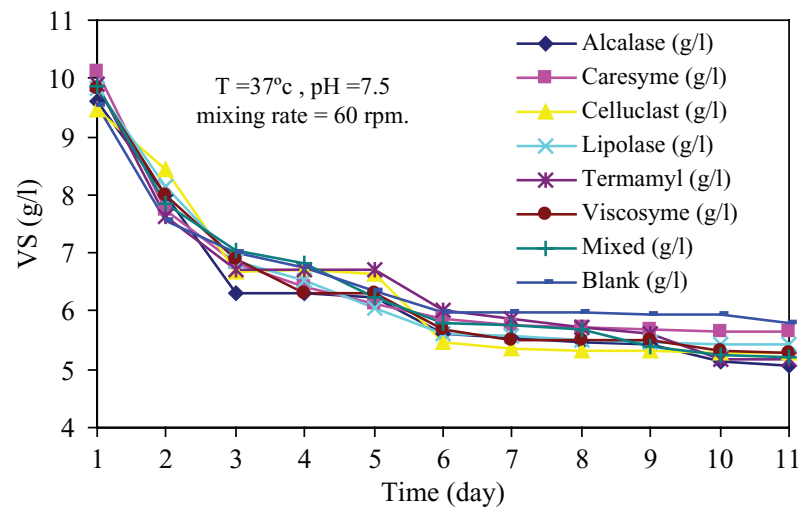

Fig. 4. Volatile Solids (VS) concentrations with change of time ( $25 \%$ digested sludge, $0.5 \%$ enzyme).

Similar results were obtained by Roman [2], where they found that the mixture of the two enzymes (Cellulase and pronase E) resulted in an $80 \%$ reduction in solids (cf. $20 \%$ in the control) and The total suspended solids (TSS) concentration was reduced by $80 \%$, from $25 \mathrm{~g} / 1$ to $5 \mathrm{~g} / \mathrm{l}$. also they found that enzyme additions were seen to decrease the production of volatile fatty acids (VFAs). Other authors [15] found that a mixture of industrial cellulase, protease, and lipase, in equal proportion by weight, reduced total suspended solids (TSS) by $30-50 \%$ and improved settling of solids.

\section{Conclusion}

The experimental work showed that:

1. The results reveal that increase of enzyme dosage from the $0.1 \%$ to $0.5 \%$ does not increase the VS reduction in that proportion. So by using $0.1 \%$ enzyme dosage acceptable results can be obtained which will reduce the pre-treatment cost.

2. The performance of individual enzymes largely depends on the characteristics of sludge. Due to difference in individual characteristics of the enzymes, one type of enzymes might be suitable for one type of sludge. The performance also depends on the enzyme dosage and the natural enzymes produced in the solids when the samples were fed with digested sludge.

3. Enzymatic pre-treatment can be successfully used as a pre-treatment step for treating sludge mixture produced from municipal wastewater treatment plant, thus improving anaerobic digestion by breakdown of large, organic particulate matter into smaller one increases the surface area available for contact with the bacteria responsible for degradation in order to improve the efficiency of digested process. 
4. Finally, the treatment and management of the sludge is a current problem all over the world. However, the needs and different solutions vary from one region to another and they are based on the technical and economical capacities of each country.

\section{References}

[1] Y. Lui, Chemically reduced excess sludge production in the activated sludge process, Chemosphere, 50 (2003) 1-7.

[2] H.J. Roman, J.E. Burgess and B.I. Pletschke, Enzyme treatment to decrease solids and improve digestion of primary sewage sludge. Afr. J. Biotechnol. 5 (10) (2006) 963-967.

[3] M.E. Griffin, K.D. McMahon, R.I. Mackie, and L. Raskin, Methanogenic Population dynamics during start-Up of anaerobic digesters treating municipal solid waste and biosolids, Biotechnol. Bioeng., 57 (3) (1998) 345-355.

[4] S.D. Watson, T. Akhurst, C.G. Whiteley, P.D. Rose and B.I. Pletschke, Primary sludge floc degradation is accelerated under biosulphidogenic conditions: enzymological aspects. Enzyme Microbial Technol., 34 (6) (2004) 595-602.

[5] C.G. Whiteley and D.J. Lee, Enzyme technology and biological remediation. Enzyme Microbial Technol., 38 (2006) 291-316.

[6] H.O. Buhr and J.F. Andrews, The thermophilic anaerobic digestion process, Water Res. II (1977) 129-143.

[7] K.V. Rajeshwari, M. Balakrishnan, A. Kansal, Kusum Lata and V.V.N. Kishore, State-of-the-art of anaerobic digestion technology for industrial wastewater treatment,. Renew. Sustain. Energy Rev., 4 (2000) 135-156.

[8] N.J. Nagle, C.J. Rivard, W.S. Adney and M.E. Himmel, Efficacy of hydrolytic enzyme augmentation and thermochemical pretreatments for increased secondary anaerobic digestion of treated municipal sewage sludges, Appl. Biochem. Biotechnol., 34/ 35 (1992) 737-751.

[9] D. Somayaji, Microbiological studies on biomethanation of mango peel with special reference to methanogens. Ph.D. thesis, University of Gulbarga, 1992.

[10] J. Mata-Alvarez, S. Mace and P. Llabres, Anaerobic digestion of organic solid wastes. An overview of research achievements and perspectives. Biores. Technol., 74 (2000) 3-16.

[11] E. Sanchez, R. Borja, L. Travieso, A. Martın and M.F. Colmenarejo, Effect of organic loading rate on the stability, operational parameters and performance of a secondary up flow anaerobic sludge bed reactor treating piggery waste. Bioresour. Technol. 96 (2005) 335-344.

[12] L. Molnar and I. Bartha, Factors influencing solid-state anaerobic digestion, Biol. Wastes, 28 (1989) 15-24.

[13] G.J. Hatziconstantinou, P. Yannakopoulos and A. Andreadakis, Primary sludge hydrolysis for biological nutrient removal. Water Sci. Technol., 34 (1-2) (1996) 417-423.

[14] Preeti C. Sangave and Aniruddha B. Pandit, Enhancement in biodegradability of distillery wastewater using enzymatic pretreatment. J. Environ. Manag., 78 (2006) 77-85.

[15] N Parmar, A Singh, O P Ward, Enzyme treatment to reduce solids and improve setting of sewage sludge, Journal of Industrial Microbiology \& Biotechnology (2001) 26, 383-386. 